\title{
Alternative method for vegetables cultivation in Benin
}

\author{
Lucia Recchia, ${ }^{1}$ Paolo Boncinelli, ${ }^{2}$ Enrico Cini ${ }^{1}$ \\ ${ }^{1}$ Dipartimento di Gestione dei Sistemi Agrari, Alimentari e Forestali (GESAAF), Università degli \\ Studi di Firenze; ${ }^{2}$ Consorzio per la Ricerca e la Dimostrazione sulle Energie Rinnovabili Re-CORD, \\ San Casciano Val di Pesa (FI), Italy
}

\begin{abstract}
In the developing countries populations, which are already vulnerable and food insecure, are likely to be the most seriously affected by the effects of climate change, e.g. yield decreases and price increases for the most important agricultural crops. The IPCC's Fourth Assessment Report for Africa describes a trend of warming at a rate faster than the global average and increasing aridity: in many parts of Africa, it seems that warmer climates and changes in precipitation will destabilise agricultural production and aggravates food security. The present work concerns the vegetables cultivation in the Parakou region in Benin, where agriculture employs approximately $70 \%$ of the active population and contributes to $36 \%$ of the Gross Domestic Product and $88 \%$ of export earnings. However, the agricultural sector has been regarded as unproductive with low adaptation capacities because of structural factors (e.g. high level of poverty among rural populations, weak mechanization and intensification of production modes), but also because of natural constraints (e.g. poor management of water and soils, leading to soil degradation). Considering the aridity, the low carbon content and the reduced level of nutrients available in the soil, the use of an hydroponic module has been hypothesised. In this way sufficient yields of the crops may be assured and no agricultural machines will be needed for the tillage operations. In addition, the nutrients can be added to the growing solution using residual materials as poultry manure, ashes and green wastes. In order to verify if some construction or maintenance problems can occur and if a growing solution can be easily obtained using agricultural wastes, some tests have been car-
\end{abstract}

Correspondence: Lucia Recchia, Dipartimento di Gestione dei Sistemi Agrari, Alimentari e Forestali (GESAAF), Università degli Studi di Firenze, P.le delle Cascine 15, 50144 Firenze, Italy.

Tel. +39.055 .3288315 - Fax: +39.055 .331794 .

Email: lucia.recchia@unifi.it

Key words: vegetables, hydroponic cultivation, African food security.

Acknowledgements: authors wish to acknowledge Mr. Riccardo Pempori and Mr. Federico Lotti which developed their Master Thesis of Agriculture in Benin, such as Eng. Badii which funded the research project on the implementation of simplified hydroponic systems in Parakou, Benin.

(C) Copyright L. Recchia et al., 2013

Licensee PAGEPress, Italy

Journal of Agricultural Engineering 2013; XLIV(s2):e165

doi:10.4081/jae.2013.s2.e165

This article is distributed under the terms of the Creative Commons Attribution Noncommercial License (by-nc 3.0) which permits any noncommercial use, distribution, and reproduction in any medium, provided the original author(s) and source are credited. ried out. Moreover laboratory analyses have been done for different solutions that may be adopted with different shares of water, poultry manure, ashes and green wastes. The tests have indicated that the hydroponic module could be used in Benin without incurring in technical problems and that a growing solution containing poultry manure, ashes and green wastes can supply to the crops a significant amount of nutrients.

\section{Introduction}

In the developing countries populations, which are already vulnerable and food insecure, are likely to be the most seriously affected by the climate change (Nelson et al., 2009), e.g. yield decreases and price increases for the most important agricultural crops. The IPCC's Fourth Assessment Report for Africa (Ziervogel et al, 2008) describes a trend of warming at a rate faster than the global average and increasing aridity: in many parts of Africa, it seems that warmer climates and changes in precipitation will destabilise agricultural production and aggravates food security. Moreover, the impacts of climate change are evident and mostly felt by the rural poor who depend on rainfed agriculture for their livelihood. Although farmers are aware of climate change and adapt differently, many are still very vulnerable in their production systems: it seems that more than $30 \%$ percent of farmers do not employ any adaptation method on their farms (Onyeneke and Madukwe, 2010). Despite the urgency of adapting to climate change, a number of factors impedes effective actions in developing countries, i.e. the low level of awareness of climate change and its risks, the lack of knowledge, the poor sharing.

Considering all these assumptions, the present work concerns a simple proposal for improving the vegetables cultivation in the Parakou region by means of introducing a simple system based on the hydroponic method. Particularly, a simplified hydroponic system has been proposed and tested: in fact, advanced hydroponic systems can be intensive and expensive, but the simplified ones are much simpler and cheaper with low operational and maintenance costs. Even if yields from such systems are lower in comparison to the advanced hydroponics, the yield still outweighs the regular farming yields.

The main aim of the simplified hydroponics is for a family to be able to feed itself and to produce a small income; it is appropriate for lowresource populations; it uses very low cost, simple technology; it requires almost no investment; it allows the growth of a wide variety of vegetables (e.g. lettuce, tomatoes, carrots, garlic, aubergine, beans, radish, leek, strawberries, melons, etc.). In brief, the hydroponic vegetable production presents the following advantages:

the produced vegetables can be of high quality and need little washing. The produced fruits and vegetables have a high biological and nutritional value, since they are harvested immediately before their use;

no good soil to grow vegetables is needed; 
soil preparation and weeding is almost eliminated;

the production presents very high yields because of the optimisation of the environmental conditions;

the water is used efficiently;

it is a low-cost and easy-to-learn technique.

The scope of the present work depends on the statement that in Benin, agriculture employs approximately $70 \%$ of the active population and contributes to $36 \%$ of the Gross Domestic Product and $88 \%$ of export earnings. However, the agricultural sector has been regarded as unproductive with low adaptation capacities because of structural factors (e.g. high level of poverty among rural populations, weak mechanization and intensification of production modes), but also because of natural constraints (e.g. poor management of water and soils, leading to soil degradation). Moreover, the soil of the small farms is often poor of nutrients and organic substance. Based on the aridity, the low carbon content and the reduced level of nutrients available in the soil, the use of an hydroponic module has been hypothesised, taking into account the necessity of reducing costs for the plant production and the system management.

\section{Materials and methods}

\section{Description of the farm}

The farm selected for this study was previously analysed and characterised by the University of Florence (Pempori, 2009). It is located in the S.Francisco Domaine, about 500 meters from the road that connects Parakou with Beterou (RNIE6) in Benin. The area is characterized by an increasing human presence living in small clusters of mud houses; the agriculture is mainly characterised by small plots of corn, peanut, soybean, sesame (Sesamum indicum) and yam. The vegetation is dense, usually dominated by tall grass (Imperata cylindrica, Striga spp.) and shrubs of various species (see Figure 1). Concerning the farm, arranged at random along its whole extension, there are various trees of cashew (Anacardium spp.), mango (Magnifera indica), shea (Vitellaria paradoxa), papaya (Carica papaya) and neem (Azadirachta spp.).

The climate is characterized by a few rainy days, with a reduced average monthly rainfall, as illustrated in Table 1. Taking into account these aspects and the presence in the farm of poultry manure and agroforestry residues, it was assumed to perform a simple hydroponic module to save water and agricultural land, allowing the reuse of wastewater directly into the field.

\section{Description of the tests}

The work is based on the results of two Master Thesis developed in 2009 (Pempori, 2009; Lotti, 2009) with a close collaboration with the local NGO Envole Afrique, that have permitted a detailed collection of climatic, agricultural and socio-economic information about the Parakou province. The work has been privately founded and developed by the GESAAF Department of the University of Florence with the support of the Re-Cord consortium for the laboratory analyses.

Firstly, a market research has been carried out identifying the adeguate hydroponic system according to the operative conditions of the typical farms in Parakou. In general two different hydroponic systems are used to produce vegetables: the open bag, or drain to waste system, and the gravel flow, or re-circulating system. In the drain to waste system, the plants grow in containers and the nutrient solution is supplied to plants by means of a dripper, for up to 12 times per day. In the gravel flow system, the nutrient solution is re-circulated and the roots of the plants stand in a thin film of nutrient solution all the time. Gravel or sand is used most often as growth medium.

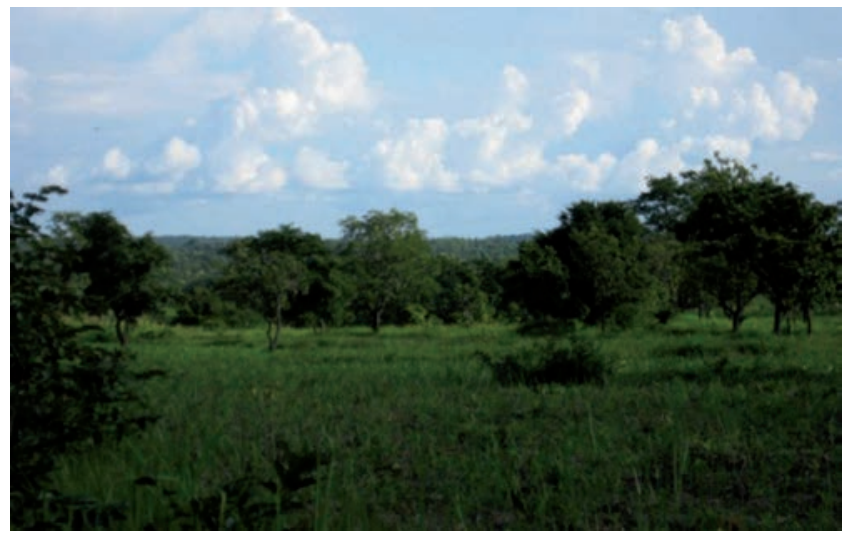

Figure 1. Example of vegetation of the farm in S. Francisco Domaine, Parakou, Benin.

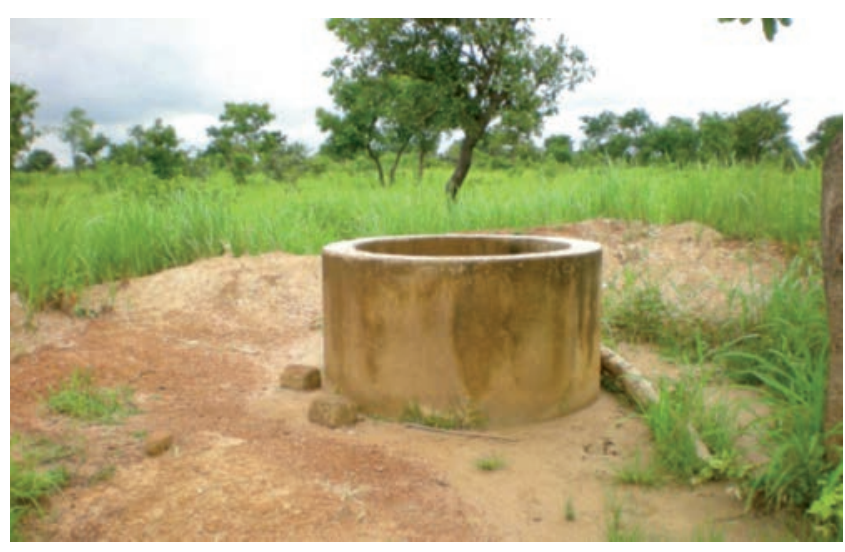

Figure 2. Well of the farm in S.Francisco Domaine, Parakou, Benin.

Table 1. Climatic data in Parakou, Benin, as monthly average of historical data from 1961 to 1990 (Source: http://gb.weather.gov.hk).

\begin{tabular}{lccccccccccccc} 
& Jan & Feb & Mar & Apr & May & Jun & Jul & Aug & Set & Oct Nov & Dec \\
Maximum temperature $\left({ }^{\circ} \mathrm{C}\right)$ & 34.1 & 36.0 & 36.2 & 34.9 & 32.8 & 30.7 & 29.2 & 28.6 & 29.5 & 31.5 & 33.6 & 33.6 & 26 \\
Average temperature $\left({ }^{\circ} \mathrm{C}\right)$ & 26.5 & 28.7 & 29.6 & 29.0 & 27.5 & 26.1 & 25.1 & 24.7 & 25.0 & 26.1 & 26.6 & 26.1 \\
\hline Minimum temperature $\left({ }^{\circ} \mathrm{C}\right)$ & 18.9 & 21.3 & 22.9 & 23.1 & 22.2 & 21.4 & 21.0 & 20.8 & 20.5 & 20.8 & 19.7 & 18.5 \\
Precipitation (mm of rain) & 3.8 & 9.2 & 39.4 & 85.5 & 130.8 & 172.0 & 189.9 & 208.8 & 205.6 & 91.1 & 6.3 & 6.6 \\
\hline Days of rain $\left(\mathrm{n}^{\circ}\right)$ & 0 & 1 & 3 & 5 & 9 & 11 & 12 & 13 & 15 & 7 & 1 & 1 \\
\hline
\end{tabular}


Considering that the technological level of the farms is very low as also the farmers knowledge, a gravel flow system has been preferred, bought and installed in a plot in Florence, Italy. The experimented system is provided by an automatic irrigation: a water tank is filled and then, thanks to gravity, the water is distributed to the plants. This layout is completely replicable in the S.Francisco Domaine where the water may be pumped from the existing well to the collection tank (see Figure 2).

Moreover, different growing solution have been applied, all obtained reusing residuals and wastes available in a typical farm of Parakou, adequately shredded and mixed with water:

Table 2. Results of the chemical analyses of a sample for 1.5 liters of the growing solution with poultry manure $(100 \%)$. The analyses have been carried out by the Re-Cord laboratory on Febrary, $20^{\text {th }} 2012$.

\begin{tabular}{lcc}
\hline Parameters & Value & Analysis method \\
$\mathrm{pH}$ (sample as received) & 10.70 & - \\
$\mathrm{pH}$ (filtered sample) & 9.93 & - \\
\hline Nitrogen (N) & $4.1 \mathrm{~g} / \mathrm{L}$ & UNI EN ISO 10304-1 \\
Phosphorus (P) & $110.4 \mathrm{~g} / \mathrm{L}$ & UNI EN ISO 10304-1 \\
\hline Potassium (K) & $19.9 \mathrm{mg} / \mathrm{L}$ & AAS method \\
Calcium (Ca) & $6.8 \mathrm{mg} / \mathrm{L}$ & AAS method \\
\hline Magnesium (Mg) & $0.2 \mathrm{mg} / \mathrm{L}$ & AAS method \\
Sodium (Na) & $4.3 \mathrm{mg} / \mathrm{L}$ & AAS method \\
\hline
\end{tabular}

Table 3. Results of the chemical analyses of a sample for 1.5 liters of the growing solution with green wastes $(88 \%)$, poultry manure $(6 \%)$ and ash $(6 \%)$. The analyses have been carried out by the Re-Cord laboratory on August, $27^{\text {th }} 2012$.

\begin{tabular}{lcc}
\hline Parameters & Value & Analysis method \\
pH (sample as received) & 7.68 & - \\
pH (filtered sample) & 8.02 & - \\
\hline Nitrogen (N) & $2.7 \mathrm{ppm}$ & UNI EN ISO 10304-1 \\
Phosphorus (P) & $12.0 \mathrm{ppm}$ & UNI EN ISO 10304-1 \\
\hline Potassium (K) & $47.7 \mathrm{ppm}$ & UNI EN 15290 (adapted) \\
Calcium (Ca) & $8.5 \mathrm{ppm}$ & UNI EN 15290 (adapted) \\
\hline Magnesium (Mg) & $7.7 \mathrm{ppm}$ & UNI EN 15290 (adapted) \\
Sodium (Na) & $5.7 \mathrm{ppm}$ & UNI EN 15290 (adapted) \\
\hline
\end{tabular}

Table 4. Results of the chemical analyses of a sample for 1.5 liters of the growing solution with green wastes $(94 \%)$, poultry manure $(3 \%)$ and ash (3\%). The analyses have been carried out by the Re-Cord laboratory on August, $27^{\text {th }} 2012$.

\begin{tabular}{lcc} 
Parameters & Value & Analysis method \\
$\mathrm{pH}$ (sample as received) & 7,98 & - \\
$\mathrm{pH}$ (filtered sample) & 8,14 & - \\
\hline Nitrogen (N) & $3,0 \mathrm{ppm}$ & UNI EN ISO 10304-1 \\
Phosphorus (P) & $21,7 \mathrm{ppm}$ & UNI EN ISO 10304-1 \\
\hline Potassium (K) & $103,7 \mathrm{ppm}$ & UNI EN 15290 (adapted) \\
Calcium (Ca) & $15,3 \mathrm{ppm}$ & UNI EN 15290 (adapted) \\
\hline Magnesium (Mg) & $6,4 \mathrm{ppm}$ & UNI EN 15290 (adapted) \\
Sodium (Na) & $12,1 \mathrm{ppm}$ & UNI EN 15290 (adapted) \\
\hline
\end{tabular}

only poultry manure $(100 \%)$;

green residuals (88\%), poultry manure (6\%), ash (6\%);

green residuals (94\%), poultry manure (3\%), ash (3\%).

Particularly, the green residuals consist of wood pruning and herbaceous crops residues. In order to measure the $\mathrm{pH}$, the nutrients and the micro-elements, the different growing solutions have been analysed.

\section{Results and discussion}

Considering that the performances of the gravel flow hydroponic system depends on the hydraulic behaviour, the system has be monitored for about 6 months and no obstructions have been noticed.

Tables 2, 3 and 4 report the results of the chemical analyses of the different growing solutions.

As results shown, the mixture of water and only poultry manure indicates that in order to correct the $\mathrm{pH}$, the addition of some vegetable component for acidifying is needed. In fact a proper $\mathrm{pH}$ value allows the plants to absorb the right nutrients for healthy growth. Moreover, the precise value of $\mathrm{pH}$ that determines the precipitation of macro-nutrients is due to the combined concentrations of calcium and sulfate: for instance, if the $\mathrm{pH}$ of the solution is too high, greater than 6.5-7.0, a precipitation of salts not absorbed by plants could stop the irrigation system.

\section{Conclusions}

The hydroponic system constitutes a good response to the agricultural difficulties in the Parakou region: sufficient yields of the crops may be assured and no agricultural machines will be needed for the tillage operations. Moreover, the proposed solution does not provide the use of chemical fertiliser, promoting the use of residual materials, as poultry manure, ashes and green wastes, that may be added to the growing solution.

Therefore, in order to verify if some construction or maintenance problems can occur and if a growing solution can be easily obtained using agro-forestry wastes, some tests have been carried out. Moreover laboratory analyses have been done for different water solutions that may be adopted mixing with different shares of water, poultry manure, ashes and green wastes.

The tests have indicated that the hydroponic module could be used without incurring in technical problems and that a growing solution containing poultry manure, ashes and green wastes can supply to the crops a significant amount of nutrients. In substance, the present study, developed at the request of the NGO Envole Afrique and privately funded, highlighted that a business improvementis feasible, also at limited or no cost. Only few years ago, this type of project was not considered viable for the implementation; currently, mainly because of the increased difference between rich and poor areas, i.e. between rich farmers and farmers who derive from agriculture the only chance of survival, the outlook seems completely opposite.

For this reason, based on the positive results obtained, a future development and implementation of the work carried out is expected: Table 5 reports a synthesis of the structure and the objectives for the future project. 
Table 5. Main structure and objectives of the future project, developing and implementing the present work.

\begin{tabular}{|c|c|c|c|c|}
\hline & Operational logics & Indicators verifiable & Validation sources & External conditions \\
\hline General objective & $\begin{array}{l}\text { Contribution at the improvement } \\
\text { of the food security and the living } \\
\text { conditions in rural areas of Parakou }\end{array}$ & & & \\
\hline Specific objective & $\begin{array}{l}\text { Increasing and diversification } \\
\text { of the agricultural production within } \\
\text { the Domaine San Francisco through } \\
\text { the cultivation of new areas }\end{array}$ & $\begin{array}{l}\text { - At the end of the project } 500 \mathrm{~m}^{2} \\
\text { of land are allocated to vegetable crops } \\
\text { - The local NGO Envole Afrique choose } \\
\text { a technician specifically trained } \\
\text { for the maintenance of the cultivated area }\end{array}$ & $\begin{array}{l}\text { - Technical reports, administrative } \\
\text { and project monitoring } \\
\text { - Statistical data } \\
\text { - Photographic documentation }\end{array}$ & $\begin{array}{l}\text { - Climatic conditions in accordance } \\
\text { with the historical data } \\
\text { - Choice of the staff }\end{array}$ \\
\hline Results & $\begin{array}{l}\text { Result 1: Construction of a small } \\
\text { irrigation system } \\
\text { Result 2: Preparation of an area } \\
\text { of } 500 \mathrm{~m}^{2} \text { for vegetables production }\end{array}$ & $\begin{array}{l}\text { - After the installation and the start-up } \\
\text { of the hydroponic kit, the irrigation } \\
\text { system is functioning and the whole } \\
\text { area has been cultivated put under } \\
\text { cultivation the area identified }\end{array}$ & $\begin{array}{l}\text { - Daily technical report of the } \\
\text { construction and the } \\
\text { maintenance of the hydraulic } \\
\text { system } \\
\text { - Daily technical report on the } \\
\text { management of the agronomic } \\
\text { practices } \\
\text { - Photographic documentation }\end{array}$ & $\begin{array}{c}\text { - Climatic conditions in accordance } \\
\text { with the historical data } \\
\text { - Availability of the water } \\
\text { - Retrieval of all the tools and } \\
\text { materials needed }\end{array}$ \\
\hline Topics & $\begin{array}{c}\text { Topic l: } \\
\text { - Identification of the site and construction } \\
\text { of the irrigation system } \\
\text { - Training of personnel on the operation } \\
\text { and maintenance of the tank and the plant } \\
\text { Topic } 2 \text { : } \\
\text { - Tillage in an area of } 500 \mathrm{~m}^{2} \text { and } \\
\text { sowing of various horticultural crops }\end{array}$ & & & \\
\hline
\end{tabular}

\section{References}

Lotti, 2009. Lotti F. Insediamento agroproduttivo in Benin: primo approccio di analisi per filiera, Master Thesis of Agriculture, University of Florence, 2009.

Nelson et al., 2009. Nelson GC, Rosegrant MW, Koo J, Robertson R, Sulser T, Zhu T, Ringler C, Msangi S, Palazzo A, Batka M, Magalhaes M, Valmonte-Santos R, Ewing M, Lee D. Climate change: impact on agriculture and costs of adaptation. International Food Policy Research Institute, Washington D.C., October 2009.
Onyeneke and Madukwe, 2010. Onyeneke RU, Madukwe DK. Adaptation measures by crop farmers in the southeast rainforest zone of Nigeria to climate change. Science World Journal, 2010, 5(1):32-34.

Pempori, 2009. Pempori R. Insediamento agroproduttivo in Benin: proposte progettuali di strutture per l'allevamento zootecnico, Master Thesis of Agriculture, University of Florence, 2009.

Ziervogel et al., 2008. Ziervogel G, Taylor A, Hachigonta S, Hoffmaister J. Climate adaptation in southern Africa: addressing the needs of vulnerable communities, Stockholm Environment Institute, Commissioned by Oxfam GB, July $15^{\text {th }}, 2008$. 